MALARIA

JOURNAL

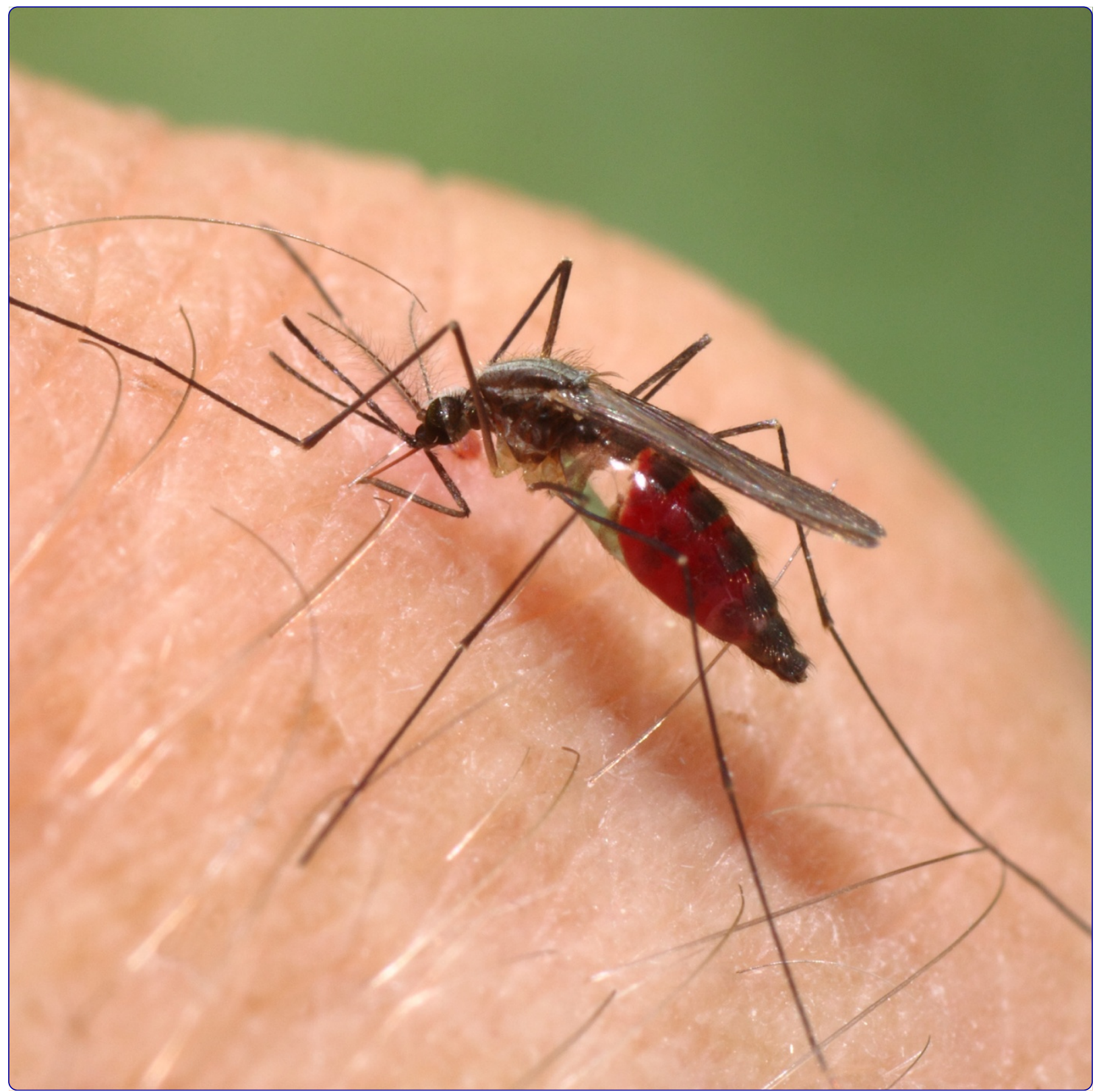

Anopheles plumbeus (Diptera: Culicidae) in Europe: a mere nuisance mosquito or potential malaria vector?

Schaffner et al.

( ) Biomed Central 


\title{
Anopheles plumbeus (Diptera: Culicidae) in Europe: a mere nuisance mosquito or potential malaria vector?
}

Francis Schaffner ${ }^{1 *}$, Isabelle Thiéry ${ }^{2}$, Christian Kaufmann ${ }^{1}$, Agnès Zettor ${ }^{2}$, Christian Lengeler $^{3}$, Alexander Mathis ${ }^{1}$ and Catherine Bourgouin ${ }^{2,4^{*}}$

\begin{abstract}
Background: Anopheles plumbeus has been recognized as a minor vector for human malaria in Europe since the beginning of the $20^{\text {th }}$ century. In recent years this tree hole breeding mosquito species appears to have exploited novel breeding sites, including large and organically rich man-made containers, with consequently larger mosquito populations in close vicinity to humans. This lead to investigate whether current populations of An. plumbeus would be able to efficiently transmit Plasmodium falciparum, the parasite responsible for the most deadly form of malaria.
\end{abstract}

Methods: Anopheles plumbeus immatures were collected from a liquid manure pit in Switzerland and transferred as adults to the CEPIA (Institut Pasteur, France) where they were fed on P. falciparum gametocytes produced in vitro. Anopheles gambiae mosquitoes served as controls. Development of $P$. falciparum in both mosquito species was followed by microscopical detection of oocysts on mosquito midguts and by sporozoite detection in the head/ thorax by PCR and microscopy.

Results: A total of 293 wild An. plumbeus females from four independent collections successfully fed through a membrane on blood containing P. falciparum gametocytes. Oocysts were observed in mosquito midguts and $P$. falciparum DNA was detected in head-thorax samples in all four experiments, demonstrating, on a large mosquito sample, that An. plumbeus is indeed receptive to P. falciparum NF54 and able to produce sporozoites. Importantly, the proportion of sporozoites-infected An. plumbeus was almost similar to that of An. gambiae (31 to 88\% An. plumbeus versus 67 to $97 \%$ An. gambiae). However, the number of sporozoites produced was significantly lower in infected An. plumbeus.

Conclusion: The results show that a sample of field-caught An. plumbeus has a moderate to high receptivity towards P. falciparum. Considering the increased mobility of humans between Europe and malaria endemic countries and changes in environment and climate, these data strongly suggest that An. plumbeus could act as a vector for malaria and thus significantly contribute to increasing the malaria transmission risk in Central-Western Europe. In locations showing high vulnerability to the presence of gametocyte carriers, the risk of transmission of malaria by An. plumbeus should be considered.

\footnotetext{
* Correspondence: francis.schaffner@uzh.ch; cabourg@pasteur.fr

${ }^{1}$ Vector Entomology Unit, Institute of Parasitology, Vetsuisse Faculty,

University of Zürich, Winterthurerstrasse 266a, Zürich CH-8057, Switzerland

${ }^{2}$ Centre de Production et d'Infection des Anophèles, Plate-forme CEPIA,

Institut Pasteur, 28 rue du Dr Roux, Paris 75724, France

Full list of author information is available at the end of the article
}

\section{Biomed Central}

(c) 2012 Schaffner et al.; licensee BioMed Central Ltd. This is an Open Access article distributed under the terms of the Creative Commons Attribution License (http://creativecommons.org/licenses/by/2.0), which permits unrestricted use, distribution, and reproduction in any medium, provided the original work is properly cited. 


\section{Background}

Global changes in health of humans and livestock are of concern to policy and decision making bodies. Over the last fifteen years, autochthonous cases and epidemic outbreaks of vector-borne diseases have occurred in Europe (e.g. bluetongue [1], chikungunya [2], dengue $[3,4]$, Schmallenberg disease [5], Usutu virus infection [6]), including local transmission of malaria in France, Germany, Greece, Italy, and Spain [7-11]. Among the factors that contribute to the emergence or re-emergence of vector-borne diseases are the increased mobility of humans, livestock, and pathogens, as well as environmental modification, and climate change [12]. This emphasizes the need to evaluate or re-evaluate the capability of European Anopheline mosquitoes to allow local transmission of malaria, in particular of Plasmodium falciparum, which is responsible for the most deadly form of the disease.

Several factors have contributed to the decline and disappearance of malaria in Western Europe and most of the Mediterranean countries during the $19^{\text {th }}$ and early $20^{\text {th }}$ centuries $[8,13]$, including improvements in socioeconomic conditions (particularly the separation of human and animal housing), the development and widespread use of efficient anti-malarial drugs, large-scale elimination of mosquito breeding sites through drainage, and improvement in mosquito control activities. Several Anopheles species had contributed to the transmission of malaria parasites in Europe, with Plasmodium vivax presumably being the prevalent species, although this is not fully ascertained [13]. The primary vector species belong to the Maculipennis complex with Anopheles atroparvus acting as the main vector in western, northern and central Europe, and Anopheles labranchiae and Anopheles sacharovi in southern regions. Other species have been considered as minor vectors, including further species of the Maculipennis complex (Anopheles messeae, Anopheles maculipennis s.s., Anopheles melanoon), as well as Anopheles algeriensis, Anopheles claviger s.s., Anopheles cinereus, Anopheles hyrcanus, Anopheles plumbeus, Anopheles sergentii, and Anopheles superpictus $[14,15]$. All the above mentioned species are still present in Europe [16,17]. Following malaria eradication campaigns, the abundance and distribution of the main vectors have been sustainably reduced in some areas but have recovered to initial levels in others $[18,19]$. The principal vectors of P. vivax (An. atroparvus, An. labranchiae, An. sacharovi) were refractory or had a low vector competence for P. falciparum in experimental investigations [20-22]. Recent studies of $A n$. labranchiae populations collected in France and Italy confirmed that this species is receptive to P. falciparum, but exhibits a low vector competence [23,24].

Anopheles plumbeus (Figure 1) is widely distributed throughout Europe (with the exception of far-northern regions), the Middle East and North Africa [16,17]. The species has been the subject of recent attention due to increased abundance in human vicinity leading to strong nuisance as this mosquito is a fierce human biter (Schaffner, unpublished; $[17,25]$ ). This increase in abundance is likely the consequence of an expansion of larval habitats. Originally known as a dendrolimnic species, breeding almost exclusively in tree holes with correspondingly small adult populations due to the scarcity of such breeding sites, this mosquito has recently been shown to exploit a wider array of larval breeding sites such as septic tanks, catch basins, tires, cemetery vases, rain water casks [25-28]. These novel breeding sites are all man-made sites, usually rich in organic matter, and indeed, all cemetery vases colonized by $A n$. plumbeus contained dead leaves (Schaffner, unpublished). Limited data are available with regard to this species' competence for human malaria. Anopheles plumbeus was incriminated as a vector of $P$. vivax $[29,30]$ and of $P$. falciparum in two cases of autochthonous malaria cases in Germany [7]. In 1920, Blacklock and Carter [31] experimentally infected one out of $11 \mathrm{An}$. plumbeus with P. falciparum. More recently, experimental feeding of An. plumbeus on blood containing P. falciparum gametocytes of the NF54 isolate led to the detection of oocysts in the midgut of three out of five mosquitoes [21] and of sporozoites in the salivary glands of six out of 10 [32].

This study shows that An. plumbeus mosquitoes from a field collection from Switzerland, with nearly three hundred females tested, are indeed competent towards P. falciparum NF54. The possibility of An. plumbeus becoming a more important vector of $P$. falciparum in Western Europe is discussed, considering the large number of malaria cases imported into the European Union

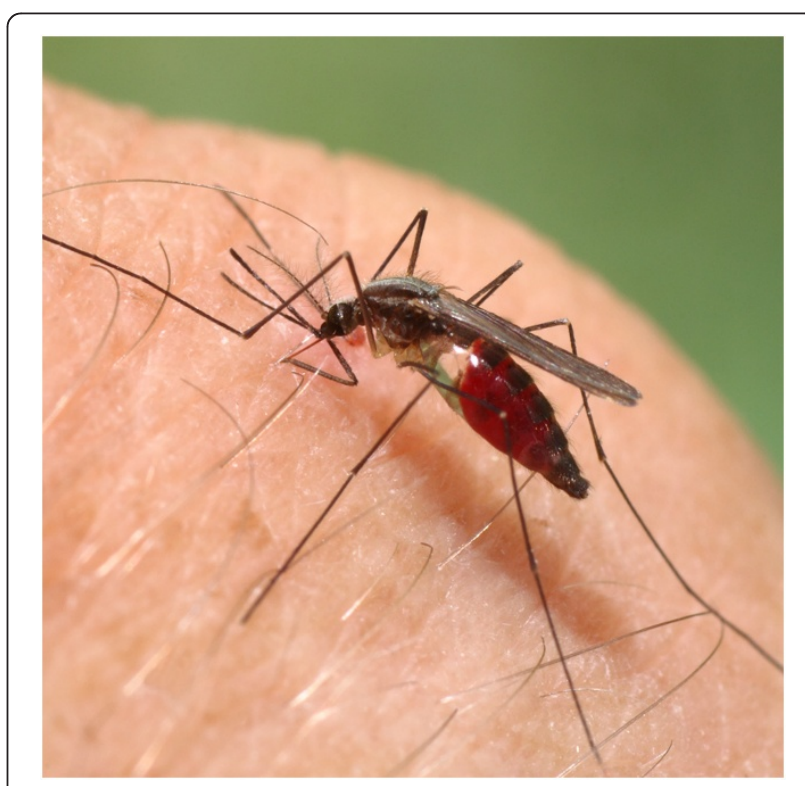

Figure 1 Anopheles plumbeus female (source: F. Schaffner/IPZ). 
every year (10,000 to 12,000 [33]) and the occurrences of episodes of higher than normal temperatures during summer $[34,35]$ which may offer a more favourable environment for autochthonous transmission of P. falciparum in temperate parts of Europe.

\section{Methods \\ Mosquitoes}

Anopheles plumbeus immatures were collected from a liquid manure pit located in Bäretswil, canton of Zurich, in a hilly region of northern Switzerland. A high number of immatures were present in this large breeding site at all visits from May to November, 2010. Immatures were sampled on four occasions (June, July, September and November 2010), reared to the adult stage in the laboratory and maintained on a $10 \%$ glucose solution at room temperature $\left(21^{\circ} \mathrm{C} \pm 2^{\circ} \mathrm{C}\right)$ and $40 \% \pm 10 \%$ relative humidity $(\mathrm{RH})$ under a $14 \mathrm{~h}-10 \mathrm{~h}$ day-night photoperiod. From each collection, 200 to 250 An. plumbeus females were sent to the CEPIA (Institut Pasteur, Paris, France) 6 days prior to $P$. falciparum challenge. Upon arrival, females were maintained under standard conditions $\left(25^{\circ} \mathrm{C} \pm 1^{\circ} \mathrm{C}\right.$, $75 \% \pm 5 \% \mathrm{RH}$ and $12 \mathrm{~h}-12 \mathrm{~h}$ day-night photoperiod) and provided a $10 \%$ sucrose solution ad libidum before being starved from sugar $24 \mathrm{~h}$ prior feeding on blood containing P. falciparum gametocytes. As a control, the $A n$. gambiae Ngousso strain, which is highly receptive to $P$. falciparum [36], was fed on the same gametocyte preparations. All An. gambiae females used as control were maintained on $10 \%$ sucrose supplemented with a $100 \mathrm{U}$ penicillin-0.01\% Streptomycin final concentration solution (Invitrogen, France) from adult emergence until the infection experiment to minimize bacterial flora and thus increase susceptibility to P. falciparum (Thiéry et al., personal communication; [37]). This treatment was not applied to An. plumbeus in order to assess its receptivity under more natural conditions.

\section{Parasites and experimental feeding}

Plasmodium falciparum isolate NF54 was cultured using a semi automated tipper table system [38], and subcultures were produced according to Mitri and colleagues [39] using fresh erythrocytes from anonymous blood donors (7\% final haematocrit) provided by ICAReB platform, Institut Pasteur. Fourteen days after initiation of the subculture, parasitemia and gametocyte sex ratio were determined on Giemsa-stained smears, and gametocyte maturity was evaluated by checking for exflagellation of microgametes. Ten $\mathrm{ml}$ of 14 day-old gametocyte culture were centrifuged at $800 \mathrm{~g}$ for $5 \mathrm{~min}$ and the pellet was resuspended in a mixture of fresh red blood cells and AB human serum (EFS, Rungis, France) to a $40 \%$ final haematocrit. One $\mathrm{ml}$ of parasitized blood was poured in each blood feeder maintained at $37^{\circ} \mathrm{C}$. The gametocyte density for the four experiments were $8.3,4.2,8.0$ and $5.7 \times 10^{7} / \mathrm{ml}$, respectively. Mosquitoes were allowed to feed in the dark through a Parafilm ${ }^{\circledR}$ membrane for $15 \mathrm{~min}$. Unengorged females were discarded while fully engorged females were transferred into small cages and provided with $10 \%$ sucrose containing $0.05 \%$ PABA (4-para-amino benzoic acid, Sigma, France) and $0.01 \%$ final concentration penicillinstreptomycin for An. gambiae only. To mimic Anopheles feeding behaviour in nature, additional uninfected fresh blood meals were provided to all mosquitoes 3 and 9 days post- $P$. falciparum ingestion (p.i.). Mosquitoes were kept at $25^{\circ} \mathrm{C}, 75 \% \mathrm{RH}$ for the duration of the experiments.

\section{Analysis of infection}

The presence of developing oocysts in mosquito midguts and of sporozoites in salivary glands was determined. Microscopic oocyst detection and quantification were performed on dissected midguts, stained with $0.1 \%$ mercuro-bromo fluorescein (Fluka, France) in phosphate buffered saline, at days 8 and 15 p.i. When available, at least 30 females per experiment and species were analysed. A female was considered infected if at least one oocyst was seen. At day 15 p.i., oocysts were recorded as either fully developed or ruptured. At this time point, the head-thorax tissue containing the salivary glands were isolated and stored at $-20^{\circ} \mathrm{C}$ for PCR detection of sporozoite DNA as described [40]. In addition, quantification of sporozoites in head-thorax tissue was performed using the Ozaki method [41].

\section{Results and discussion}

A total of 293 wild An. plumbeus females successfully fed through a membrane on blood containing P. falciparum gametocytes. Oocysts were observed at days 8 and 15 p.i. in mosquito midguts. In addition, P. falciparum DNA was detected in head-thorax samples in all four experiments. These results confirm, on a large mosquito sample, that $A n$. plumbeus is receptive to $P$. falciparum NF54 infection and able to produce sporozoites (prevalence $31-88 \%$ ). Detailed analysis of the results demonstrates that this European mosquito species has moderate to high receptivity to $P$. falciparum, compared to the CEPIA's reference strain An. gambiae (Table 1). On day 15 after gametocyte ingestion, oocysts developed in 10 to $75 \%$ of $A n$. plumbeus mosquitoes, while 67 to $100 \% A n$. gambiae harboured oocysts. At this time point, the overall mean number of oocysts developing in An. plumbeus (228.8) was lower than of An. gambiae (10.7-44.8). Comparing the infection prevalence at day 8 and day 15 reveals a slight decrease in An. gambiae while the opposite occurred in An. plumbeus. The decrease in An. gambiae prevalence could be due to the difficulty of detecting ruptured oocysts. The slight increase in An. plumbeus prevalence is suggestive of a slower development of $P$. 
Table 1 Plasmodium falciparum infection and dissemination in field-caught An. plumbeus and laboratory-reared An. gambiae Ngousso

\begin{tabular}{|c|c|c|c|c|c|c|c|c|c|}
\hline & \multirow[b]{2}{*}{$\begin{array}{l}\text { Day of } \\
\text { observation }^{a}\end{array}$} & \multicolumn{4}{|c|}{ Anopheles plumbeus } & \multicolumn{4}{|c|}{ Anopheles gambiae Ngousso } \\
\hline & & Exp. 1 & Exp. $2^{b}$ & Exp. 3 & Exp. 4 & Exp. 1 & Exp. 2 & Exp. 3 & Exp. 4 \\
\hline \multirow{4}{*}{$\begin{array}{l}\text { Prevalence (\%) of midgut infection } \\
\text { (no. positive / no. analysed) }\end{array}$} & \multirow[t]{2}{*}{8} & 67 & \multirow[t]{2}{*}{$\mathrm{nd}^{\mathrm{c}}$} & 40 & 4 & 100 & 100 & 87 & 73 \\
\hline & & $(20 / 30)$ & & $(12 / 30)$ & $(1 / 24)$ & $(30 / 30)$ & $(30 / 30)$ & $(26 / 30)$ & $(22 / 30)$ \\
\hline & \multirow[t]{2}{*}{15} & 75 & 15 & 43 & 10 & 100 & 100 & 67 & 70 \\
\hline & & $(36 / 48)$ & $(2 / 13)$ & $(22 / 51)$ & $(7 / 70)$ & $(32 / 32)$ & $(24 / 24)$ & $(20 / 30)$ & $(21 / 30)$ \\
\hline \multirow{4}{*}{ 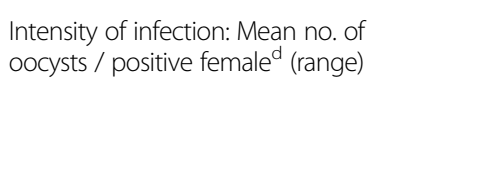 } & \multirow[t]{2}{*}{8} & $8.9 \pm 6.3$ & \multirow[t]{2}{*}{$n d^{c}$} & $50.4 \pm 56.0$ & $12.0 \pm 0$ & $42.4 \pm 28.2$ & $71.5 \pm 63.3$ & $29.5 \pm 23.5$ & $13.7 \pm 13.6$ \\
\hline & & $(2-25)$ & & $(1-171)$ & (12) & $(3-122)$ & $(1-233)$ & $(1-74)$ & $(1-48)$ \\
\hline & \multirow[t]{2}{*}{15} & $5.3 \pm 4.9$ & $2.0 \pm 0$ & $28.8 \pm 14.4$ & $2.4 \pm 2.1$ & $22.4 \pm 25.2$ & $44.8 \pm 36.4$ & $26.4 \pm 23.7$ & $10.7 \pm 10.1$ \\
\hline & & $(1-18)$ & (2) & $(4-63)$ & $(1-6)$ & $(1-112)$ & $(1-146)$ & $(1-79)$ & $(1-45)$ \\
\hline \multirow{2}{*}{$\begin{array}{l}\text { Prevalence (\%) of females with sporozoites } \\
\text { (no. positive / no. analysed) }\end{array}$} & \multirow[t]{2}{*}{15} & 83 & 31 & 88 & 57 & 97 & 88 & 67 & 70 \\
\hline & & $(40 / 48)$ & $(4 / 13)$ & $(45 / 51)$ & $(40 / 70)$ & $(31 / 32)$ & $(21 / 24)$ & $(20 / 30)$ & $(21 / 30)$ \\
\hline \multirow{2}{*}{$\begin{array}{l}\text { Intensity of infection: Mean no. sporozoites / } \\
\text { positive female (no. analysed) }\end{array}$} & \multirow[t]{2}{*}{15} & 1,620 & \multirow[t]{2}{*}{$\mathrm{nd}^{\mathrm{c}}$} & 108 & \multirow[t]{2}{*}{$n d^{c}$} & 11,178 & 25,623 & 15,755 & 950 \\
\hline & & (12) & & (15) & & (30) & (30) & (30) & (30) \\
\hline
\end{tabular}

Experiments 1 to 4 were performed in June, July, September and November, 2010, respectively.

after exposure to $P$. falciparum gametocytes.

b Low number of An. plumbeus mosquitoes due to high mortality during transport.

c Not determined.

d Positive females are females with at least 1 detectable oocyst.

e PCR detection [40] of $P$. falciparum DNA isolated from head/thorax.

${ }^{f}$ Sporozoite quantification was performed using the Ozaki method [41]; total number was normalized to the oocyst prevalence at day 8 .

falciparum in this species, with oocysts continuing their development between day 8 and day 15 . However, in both species the mean number of oocysts decreased between day 8 and day 15, which, as mentioned above, is likely the result of the inability to detect oocysts that had ruptured. Therefore, the apparent discrepancy between increased prevalence of infection and decreased oocyst mean intensity at day 15 for An. plumbeus is suggestive of asynchrony of $P$. falciparum development in this mosquito species under this experimental setting. Importantly, the proportion of An. plumbeus harbouring sporozoites is high, ranging from 31 to $88 \%$, not very much different from the proportion of sporozoite-positive An. gambiae (67 to 97\%). This prevalence of sporozoite infection is higher than the prevalence of oocyst infection at days 8 or 15 , which is not surprising considering the proportion of mosquitoes with few or undetectable oocysts and the sensitivity of PCR. The presence of sporozoites in $A n$. plumbeus was then confirmed using the Ozaki method in the two experiments involving a large sample size and showing high oocyst prevalences (experiments 1 and 3, Table 1). The quantity of sporozoites was nevertheless lower than in An. gambiae when estimated per female harbouring at least one oocyst at day 15 . This finding is consistent with the reduced oocyst load in An. plumbeus.

Anopheles plumbeus has been described as a putative vector for $P$. vivax under central European $[29,42]$ and Russian climate conditions [30]. Studies have found that it is a more efficient carrier of $P$. vivax than $A n$. atroparvus and An. claviger [43]. The first experimental demonstration of An. plumbeus competence towards $P$. vivax and $P$. falciparum were reported nearly 100 years ago $[31,44,45]$. Anopheles plumbeus competence towards $P$. vivax has not been experimentally reevaluated since, mainly due to the difficulty of access to $P$. vivax gametocytes. In contrast, An. plumbeus ability to permit $P$. falciparum development to the sporozoite stage was recently shown under laboratory conditions on a sample of ten mosquitoes [32]. The present study demonstrates the development of $P$. falciparum sporozoites, the stage infective to humans, in a wild population of $A n$. plumbeus and for a large number of specimens $(\mathrm{n}=293)$ collected at different times during the yearly natural occurrence of the species. Although these results show that An. plumbeus developed less P. falciparum oocysts than An. gambiae, the proportion of mosquitoes harbouring sporozoites was similar in both species. Associated with its fierce human biting (see below), these data indicate that An. plumbeus could play a significant role for local transmission of $P$. falciparum where there is imported malaria. In comparison, An. labranchiae, which is believed to have played a significant role in indigenous malaria transmission in parts of Europe, showed a lower prevalence of P. falciparum sporozoite infection (3 to 10\%) in two independent sets of infections performed under similar conditions $[23,24]$. 
Parasite transmission depends on multiple factors which define the vectorial capacity $\mathrm{C}$, i.e. the daily rate of future inoculations originating from a currently infective source, in the equation $\mathrm{C}=\mathrm{b} \mathrm{m} \mathrm{a} \mathrm{a}^{2} \mathrm{pt} /(-\ln \mathrm{p})$ [46], where $\mathrm{b}$ is the vector competence, i.e. the proportion of vectors that develop infective parasite stages; $m$ the vector density in relation to host density; a the vector's daily blood-feeding rate; $\mathrm{p}$ the vector's daily survival rate; $\mathrm{t}$ the duration of the parasite's extrinsic incubation period in days. Thus, besides being competent to P. falciparum, a mosquito species needs to both sustain parasite development upon natural temperature ranges and have a daily survival rate high enough to transmit the parasite to humans.

In the experimental setting of the presented work, mosquitoes were maintained at a constant temperature of $25^{\circ} \mathrm{C}$, which corresponds to the mean temperature range of July in the subtropical Mediterranean climate. Thus, the observed infectivity of $P$. falciparum can be expected to be similar under natural conditions for southern Europe. At this temperature, the extrinsic incubation period of $P$. falciparum is $12-14$ days, which increases to $22-23$ days at $20^{\circ} \mathrm{C}$ [47]. Considering the longevity of $A n$. plumbeus of up to two months [42], completion of parasite development to the sporozoite stage under cooler conditions is feasible. Furthermore, recent studies indicate that, at low mean average temperatures, parasite development is faster under realistic daily fluctuating temperatures as compared to corresponding constant temperatures [48]. Altogether this suggests that $A n$. plumbeus could be a competent vector for P. falciparum in a Central European climate.

Additional evidence of a possible role for $A n$. plumbeus in the transmission of malaria comes from its ability to feed on humans (factor a), often in large numbers (factor $\mathrm{m}$ ), due to the proliferation of this species in large man-made containers such as abandoned manure pits [16,17,25]. For example, in Alsace (north-eastern France) during the 1990's, populations of An. plumbeus expanded leading to the observation of human leg landing rates of up to 365 individuals in 15 minutes (Schaffner, unpublished). At this time, the highest infestation rate was located nearby the international Basel-Mulhouse-Freiburg airport.

The source of the An. plumbeus used in this study was an abandoned manure pit which was discovered during mosquito field surveys in Switzerland in 2007-2010. During these surveys, An. plumbeus was the most frequently collected Anopheles species, being reported in 40 out of 396 mosquito collections (34 larval samplings; 6 adult catches/trapping of which 5 human landing catches, one BG-Sentinel ${ }^{\mathrm{Tm}}$ trapping) from all urban, suburban, rural, and nature land-use zones from an altitudinal range from 268 to $858 \mathrm{~m}$ above sea level. In contrast, An. claviger s.s., An. maculipennis s.s. and $A n$. messeae were reported at 22, 18 , and three locations, respectively (Schaffner, unpublished data). Additionally, An. plumbeus was the third most common species after Culex pipiens and Aedes japonicus found in 3,000 vases in Swiss cemeteries, screened for invasive Aedes species such as Aedes albopictus [27].

\section{Conclusions}

Taking into account human and parasite movements and changes in environment and climate, the data presented strongly suggest that An. plumbeus can play the vector role for malaria and can significantly contribute to increase the malaria transmission risk in Central-Western Europe for both $P$. vivax and $P$. falciparum, due to (1) its proven vector competence for these two parasites, (2) the occurrence of locally high population densities as a result of the recently established exploitation of man-made breeding habitats, (3) the aggressiveness of this species to humans and (4) its longevity for up to two months enabling the parasites to complete their development to the sporozoite stage. In localities showing high vulnerability for the presence of gametocyte carriers, the risk of transmission of malaria by An. plumbeus should be considered.

\section{Competing interests}

The authors declare that they have no competing interests.

\section{Authors' contributions}

FS conceived the study and collected the wild mosquito populations. CK contributed to the wild mosquito rearing. IT and AZ performed the experimental infections. FS, CB, IT, AM and CL participated in the data analysis and interpretation and helped to draft the manuscript. All authors read and approved the final manuscript.

\section{Acknowledgements}

We thank the CEPIA technicians for rearing An. gambiae mosquitoes, the ICAReB Platform for providing human blood samples used for the in vitro production of Plasmodium gametocytes and the farmer for providing access to the larval breeding site. We highly acknowledge the Swiss Federal Veterinary Office for funding FS as collaborator of the Swiss Reference Laboratory for Epizootic Vectors, and the Swiss Tropical and Public Health Institute for co-funding this study.

\section{Author details}

${ }^{1}$ Vector Entomology Unit, Institute of Parasitology, Vetsuisse Faculty, University of Zürich, Winterthurerstrasse 266a, Zürich CH-8057, Switzerland. ${ }^{2}$ Centre de Production et d'Infection des Anophèles, Plate-forme CEPIA, Institut Pasteur, 28 rue du Dr Roux, Paris 75724, France. 'Swiss Tropical and Public Health Institute, Socinstrasse 57, Basel CH-4002, Switzerland. ${ }^{4}$ Present address: Genetics and Genomics of Insect Vectors, Institut Pasteur, 28 rue du Dr Roux, Paris 75724, France.

Received: 21 October 2012 Accepted: 22 November 2012 Published: 26 November 2012

\section{References}

1. Wilson AJ, Mellor PS: Bluetongue in Europe: past, present and future. Phil Trans R Soc B 2009, 364:2669-2681.

2. Rezza G, Nicoletti L, Angelini R, Romi R, Finarelli AC, Panning M, Cordioli P, Fortuna C, Boros S, Magurano F, Silvi G, Angelini P, Dottori M, Ciufolini MG, Majori GC, Cassone A, for the CHIKV study group: Infection with chikungunya virus in Italy: an outbreak in a temperate region. Lancet 2007, 370:1840-1846. 
3. Gould EA, Gallian P, De Lamballerie X, Charrel RN: First cases of autochthonous dengue fever and chikungunya fever in France: from bad dream to reality! Clin Microbiol Infect 2010, 16:1702-1704.

4. Gjenero-Margan I, Aleraj B, Krajcar D, Lesnikar V, Klobučar A, Pem-Novosel I, Kurečić-Filipović S, Komparak S, Martić R, Đuričić S, Betica-Radić L, Okmadžić J, Vilibić-Čavlek T, Babić-Erceg A, Turković B, Avšić-Županc T, Radić I, Ljubić M, Šarac K, Benić N, Mlinarić-Galinović G: Autochthonous dengue fever in Croatia, August-September. Euro Surveill 2011, 16:pii=19805.

5. Rasmussen LD, Kristensen B, Kirkeby C, Rasmussen TB, Belsham GJ, Bødker R, Bøtner A: Culicoids as vectors of Schmallenberg virus. Emerg Infect Dis 2012, 18:1204-1206

6. Steinmetz HW, Bakonyi T, Weissenbock H, Hatt JM, Eulenberger U, Robert N, Hoop R, Nowotny N: Emergence and establishment of Usutu virus infection in wild and captive avian species in and around Zurich, Switzerland - Genomic and pathologic comparison to other central European outbreaks. Vet Microbiol 2011, 148:207-212.

7. Krüger A, Rech A, Su XZ, Tannich E: Two cases of autochthonous Plasmodium falciparum malaria in Germany with evidence for local transmission by indigenous Anopheles plumbeus. Trop Med Int Health 2001, 6:983-985

8. Alten B, Kampen H, Fontenille D: Malaria in Southern Europe: resurgence from the past? In Emerging pests and vector-borne diseases in Europe. Edited by Takken W, Knols BG. Wageningen: Wageningen Academic Publishers; 2007:35-57.

9. Zoller T, Naucke TJ, May J, Hoffmeister B, Flick H, Williams CJ, Frank C, Bergmann F, Suttorp N, Mockenhaupt FP: Malaria transmission in nonendemic areas: case report, review of the literature and implications for public health management. Malar J 2009, 8:71.

10. Santa-Olalla Peralta P, Vazquez-Torres MC, Latorre-Fandos E, Mairal-Claver $P$, Cortina-Solano P, Puy-Azón A, Adiego Sancho B, Leitmeyer K, Lucientes-Curdi J, Sierra-Moros MJ: First autochthonous malaria case due to Plasmodium vivax since eradication, Spain, October 2010. Euro Surveill 2010, 15:pii=19684.

11. Danis K, Baka A, Lenglet A, Van Bortel W, Terzaki I, Tseroni M, Detsis M, Papanikolaou E, Balaska A, Gewehr S, Dougas G, Sideroglou T, Economopoulou A, Vakalis N, Tsiodras S, Bonovas S, Kremastinou J: Autochthonous Plasmodium vivax malaria in Greece, 2011. Euro Surveill 2011, 16:pii=19993.

12. Randolph SE, Rogers DJ: The arrival, establishment and spread of exotic diseases: patterns and predictions. Nat Rev Microbiol 2010, 8:361-371.

13. Bruce-Chwatt $L$, De Zulueta J: The rise and fall of malaria in Europe: $A$ historico-epidemiological study. Oxford: Oxford University Press; 1980.

14. Hackett LW: Malaria in Europe. An ecological study. London: Oxford University Press; 1937.

15. Zahar AR: Vector bionomics in the epidemiology and control of malaria. Part II. The WHO European Region \& the WHO Eastern Mediterranean Region. Vol II: Applied field studies. Geneva: World Health Organisation; 1990.

16. Schaffner F, Angel G, Geoffroy B, Hervy J-P, Rhaiem A, Brunhes J: The Mosquitoes of Europe. An identification and training programme. Montpellier: IRD Editions \& EID Méditerranée; 2001. CD-Rom.

17. Becker N, Petrić D, Zgomba M, Boase C, Madon M, Dahl C, Kaiser A: Mosquitoes and their control. 2nd edition. Heidelberg: Springer-Verlag; 2010.

18. Blazquez J, De Zulueta J: The disappearance of Anopheles labranchiae from Spain. Parassitologia 1980, 22:161-163.

19. Romi R, Pierdominici G, Severini C, Tamburro A, Cocchi M, Menichetti D, Pili E, Marchi A: Status of malaria vectors in Italy. J Med Entomol 1997, 34:263-271.

20. Daškova NG, Rasnicyn SP: Review of data on susceptibility of mosquitoes in the USSR to imported strains of malaria parasites. Bull World Health Organ 1982, 60:893-897.

21. Marchant P, Eling W, van Gemert GJ, Leake CJ, Curtis CF: Could British mosquitoes transmit Falciparum malaria? Parasitol Today 1998, 14:344-345.

22. Sousa C: Malaria vectorial capacity and competence of Anopheles atroparvus Van Thiel, 1927 (Diptera, Culicidae): Implications for the potential re-emergence of malaria in Portugal, PhD thesis. Lisbon: Universidade Nova de Lisboa; 2008.

23. Toty C, Barré H, Le Goff G, Larget-Thiéry I, Rahola N, Couret D, Fontenille D: Malaria risk in Corsica, former hot spot of malaria in France. Malar J 2010, 9:231.

24. Romi R, Boccolini D, Vallorani R, Severini F, Toma L, Cocchi M, Tamburro A, Messeri G, Crisci A, Angeli L, Costantini R, Raffaelli I, Pontuale G, Thiéry I, Landier A, Le Goff G, Fausto AM, Di Luca M: Assessment of the risk of malaria re-introduction in the Maremma plain (Central Italy) using a multi-factorial approach. Malar J 2012, 11:98.

25. Dekoninck W, Hendrickx F, Van Bortel W, Versteirt V, Coosemans M, Damien D, Hance T, De Clercq EM, Hendrickx G, Schaffner F, Grootaert P: Human induced expanded distribution of Anopheles plumbeus, experimental vector of West Nile virus and a potential vector of human malaria in Belgium. J Med Entomol 2011, 48:924-928.

26. Schaffner F: Mosquitoes in used tyres in Europe: species list and larval key. Eur Mosa Bull 2003, 16:7-12.

27. Schaffner F, Kaufmann C, Hegglin D, Mathis A: The invasive mosquito Aedes japonicus in Central Europe. Med Vet Entomol 2009, 23:448-451.

28. Bueno-Marí R, Jiménez-Peydró R: Anopheles plumbeus Stephens, 1828: a neglected malaria vector in Europe. Malaria Reports 2011, 1:e2.

29. Shute PG, Maryon M: Malaria in England past, present and future. Roy Soc Health J 1974, 94:23-29.

30. Sokolova MI, Snow KR: Malaria vectors in European Russia. Eur Mosq Bull 2002, 12:1-6.

31. Blacklock B, Carter HF: Further experiments with Anopheles plumbeus Stephens, its infection with P. falciparum in England; Also notes on the apparatus and technique employed. Ann Trop Med Par 1920, 13:275-283.

32. Eling W, van Gemert G-J, Akinpelu O, Curtis J, Curtis CF: Production of Plasmodium falciparum sporozoites by Anopheles plumbeus. Eur Mosa Bull 2003, 15:12-13.

33. World Health Organization: From malaria control to elimination in the WHO European Region 2006-2015. Regional Strategy. Copenhagen: World Health Organization, Regional Office for Europe; 2006.

34. Luterbacher J, Dietrich D, Xoplaki E, Grosjean M, Wanner H: European seasonal and annual temperature variability, trends, and extremes since 1500. Science 2004, 303:1499-1503.

35. Xoplaki E, Luterbacher J, Paeth H, Dietrich D, Steiner N, Grosjean MHW: European spring and autumn temperature variability and change of extremes over the last half millennium. Geophys Res Lett 2005, 32:L15713.

36. Mitri C, Jacques J-C, Thiéry I, Riehle MM, Xu J, Bischoff E, Morlais I, Nsango $\mathrm{SE}$, Vernick KD, Bourgouin C: Fine pathogen discrimination within the APL1 gene family protects Anopheles gambiae against human and rodent malaria species. PLOS Pathog 2009, 5:e1000576.

37. Rodrigues J, Brayner FA, Alves LC, Dixit R, Barillas-Mury C: Hemocyte differentiation mediates innate immune memory in Anopheles gambiae mosquitoes. Science 2010, 239:1353-1355

38. Ponnudurai T, Meuwissen JHET, Leeuwenberg ADEM, Verhave JP, Lensen AHW: The production of mature gametocytes of Plasmodium falciparum in continuous cultures of different isolates infective to mosquitoes. Trans R Soc Trop Med Hyg 1982, 76:242-250.

39. Mitri C, Thiéry I, Bourgouin C, Paul REL: Density-dependent impact of the human malaria parasite Plasmodium falciparum gametocyte sex ratio on mosquito infection rates. Proc R Soc Bio/ Sci B 2009, 276:3721-3726.

40. Padley D, Moody AH, Chiodini PL, Saldanha J: Use of a rapid, single-round, multiplex PCR to detect malarial parasites and identify the species present. Ann Trop Med Parasitol 2003, 97:131-137.

41. Ozaki LS, Gwadz RW, Godson GN: Simple centrifugation method for rapid separation of sporozoites from mosquitoes. J Parasitol 1984, 70:831-833.

42. Shute PG: Indigenous $P$. vivax malaria in London believed to have been transmitted by Anopheles plumbeus. Mon Bull Minist Health Publ Health Lab Serv 1954, 13:48-51.

43. James SP: The disappearance of malaria from England. Proc $R$ Soc Med 1929, 23:1-15.

44. Blacklock B, Carter HF: The experimental infection, in England, of Anopheles plumbeus with Plasmodium vivax (sporozoites in salivary glands). Preliminary note. Ann Trop Med Parasitol 1919, 13:187-188.

45. Blacklock B, Carter HF: The experimental infection in England, of Anopheles plumbeus Stephens and Anopheles bifurcatus with Plasmodium vivax. Ann Trop Med Parasitol 1920, 13:413-420.

46. Scott TW, Takken W: Feeding strategies of anthropophilic mosquitoes result in increased risk of pathogen transmission. Trends Parasitol 2012, 28:114-121.

47. Anonymous: Manual on practical entomology in malaria. Part Il: Methods and Techniques. Geneva: World Health Organization; 1975.

48. Paaijmans KP, Blanford S, Bell AS, Blanford Jl, Read AF, Thomas MB: Influence of climate on malaria transmission depends on daily temperature variation. Proc Natl Acad Sci USA 2010, 107:15135-15139.

\section{doi:10.1186/1475-2875-11-393}

Cite this article as: Schaffner et al:: Anopheles plumbeus (Diptera:

Culicidae) in Europe: a mere nuisance mosquito or potential malaria vector?. Malaria Journal 2012 11:393. 